\title{
自動車用空調シロッコファンの騒音発生機構に関する研究*
}

\author{
酒 井 康 彦*1, 加 藤 高 章*2, 森口 優*2 \\ 酒井雅 晴*3, 伊藤功 治*3, 三石康志*4 \\ 長田孝二*5, 久保 貴*5
}

\section{On the Mechanism of Noise Generation in the Sirocco Fan for Automobile Air Conditioner}

\author{
Yasuhiko SAKAI*6, Takaaki KATO, Yuu MORIGUCHI, \\ Masaharu SAKAI, Kouji ITO, Yasushi MITSUISHI, \\ Kouji NAGATA and Takashi KUBO \\ ${ }^{* 6}$ Department of Mechanical Science and Engineering, Nagoya University, \\ Furo-cho, Chikusa-ku, Nagoya-shi, Aichi, 464-8603 Japan
}

\begin{abstract}
The final purpose of this study is to clarify the relation between the static pressure fluctuation between fan blades and the noise emitted to the outside of the fan. For this purpose, first of all, a new micro probe for the measurement of the static pressure fluctuation has been developed. The measurement of the static pressure fluctuation between the blades has been performed, and the intensity of sound source was quantified from the second derivative of phase averaged static pressure fluctuation signal $\left(\operatorname{Ribner}^{(2)}\right)$. It is shown that the intensity of sound source becomes largest when the blade approaches to the tongue. The difference between the cooling mode and the heating mode are also investigated. It is found that the sound source for cooling mode shows the larger value than that for heating as a whole.
\end{abstract}

Key Words: Fluctuating Pressure, Aerodynamic Noise, Turbulence, Micro Pressure Probe, Sirocco Fan, Car Air-Conditioning System

1. は じめ に

本研究の目的は自動車用空調シロッコファンの騷音 発生機構を実験的に解明することである. シロッコファ ンでは, 羽根車からの放射音が主な騒音源になること が知られている ${ }^{(1)}$. 音源に関する Ribner の膨張理論 (2) (3)では, 音源項が流れ中の静圧変動の時間に関する 二階微分であるとし, 静圧変動と音の圧力変動の関係 式が導き出されている.この関係式に基づき，流れ中 の変動静圧を計測することで音源と音の強さの関係を 検討することが可能になると考えられる.

本研究ではまず，シロッコファン翼間に設置でき， かつ変動静圧測定可能な小型の L 字型静圧管の開発を 行った. そしてこの静圧管を用いた静圧管プローブの 各種検定を行い, その有効性を検証した. 次に,この

* 原稿受付 2008 年 4 月 11 日.

*1 正員, フェロー, 名古屋大学大学院工学研究科 (\$ 464-8603 名古屋市千種区不老町)

*2 名古屋大学大学院工学研究科.

*3 (株) デンソー(画 448-8661 刈谷市昭和町 1-1).

*4 (株) 日本自動車部品総合研究所( $\mathbf{E} 445-0012$ 西尾市下羽角 町岩谷 14).

*5 正員, 名古屋大学大学院工学研究科.

E-mail : ysakai@mech.nagoya-u.ac.jp
静圧管プローブを用いて自動車用空調シロッコファン の翼間変動静圧を測定し，その時間に関する二階微分 値を求めることにより音源項の定量化を試みた.さら に, 定量化した音源項の回転角 $30^{\circ}$ 毎の位相平均を評 価することで音源の強い位置を特定した．本報ではこ れらについて報告する。

\section{Ribner の膨張理論}

Ribner の式は Lighthill の式を発展させたものであ り，次式で表される(2)(3).

$$
\frac{\partial^{2} p^{(1)}}{\partial t^{2}}-c_{0}^{2} \nabla^{2} p^{(1)}=-\frac{\partial^{2} p^{(0)}}{\partial t^{2}}
$$

ここで, $c_{0}$ は音速, $p^{(0)}$ は非圧縮流れ中の静圧変動, $p^{(1)}$ は放射される音の圧力変動である.この Ribnerの 式は, 音の圧力変動が流れ中の変動静圧の時間に関す る二階微分值を音源として, 波動となって伝播するこ とを示している.

\section{3. 変動静圧プロープ}

3.1 変動静圧プロープの設計に対する留意点 変 動静圧の計測法については文献 (4)に詳しく記載され 
ているが，ここでは実際に今回，変動静圧プローブを 設計・製作するために特に留意した点をまとめる ${ }^{(4) \sim(6)}$. 理想的に変動静圧を計測するには計器を流れと共に 流動させて静圧を読み取ることが必要であるが，これ は実際上困難であり，流れ内部で静圧を測る場合には 空間中に固定した静圧管を用いることが一般的である. しかし, 静圧管による計測は流れに対する傾きの影響 を強く受ける.すなおち, 傾きが大きくなれば静圧管 に沿う流れが下流で剥離し, 管の周囲で圧力の不均一 が起きる. そのため, 静圧の計測には流れをできるだ け乱さないことが必要な条件である. 従って, 流れを 乱すことなく，流れに対する傾きに鈍感な静圧管を開 発することが非常に重要となる.

また，静圧管を用いて変動静圧を測定する際，その 静圧管の共鳴周波数が問題となる. 図 1 に示すような 形状の静圧管プローブがあるとする. 図中, $p_{1}$ は測圧 孔にかかる圧力の值 (これは, 導管内の圧力の值と近 似的に同じであると考えられる)であり， $p_{2}$ は実際に 測定される受圧室での圧力の值である.また, $d_{1}, d_{2}$ はそれぞれ導管の内径及び受圧室の内径に対応し, $l_{1}$ は測圧孔から受圧室までの距離, $l_{2}$ は受圧室の深さで ある. $q$ は測圧孔と導管を通って受圧室に流入する体 積流量である.このとき, 静圧管全体のへルムホルツ 共鳴周波数 $f_{n 1}$, 及びオルガンパイプ共鳴周波数 $f_{n 2}$ は

$$
\begin{gathered}
f_{n 1}=\frac{c_{0}}{2 \pi} \frac{d_{1}}{d_{2}} \sqrt{\frac{1}{k l_{1} l_{2}}}, \quad k=1+\frac{8 d_{1}}{3 \pi l_{1}} \\
f_{n 2}=\frac{c_{0}}{2 l_{1}}
\end{gathered}
$$

となる ${ }^{(5)}$.ここで, $c_{0}$ は音速である. 例えば, 本研究で 用いたプローブの場合， $d_{1}=0.30 \mathrm{~mm}, d_{2}=1.80 \mathrm{~mm}$, $l_{1}=10.4 \mathrm{~mm}$ (直線として考えた場合), $l_{2}=0.31 \mathrm{~mm}$ であるので，これらの数值を代入すると， $f_{n 1}=4960$ $\mathrm{Hz}, f_{n 2}=16300 \mathrm{~Hz}$ となる. ヘルムホルツ共鳴は導管 の断面積 $A_{1}=\pi d_{1}^{2} / 4$ と長さ $l_{1}$ および受圧室空隙の体 積 $V_{2}=A_{2} l_{2}$ (ここで, $\left.A_{2}=\pi d_{2}^{2} / 4\right)$ に依存し, 空隙を 導管につないだために生じる共鳴である。これらの共 鳴周波数を高くすることも静圧管を開発する上で重要 となる。

3.2 マイクロ静圧管の設計 図 2 に本研究で設 計·製作した静圧管を示す.この静圧管は直径 $0.55 \mathrm{~mm}$, 内径 $0.3 \mathrm{~mm}$ であり, 直径 $0.1 \mathrm{~mm}$ の静圧孔が 4 孔設 けられている. 圧力センサは半導体トランスデューサ (Kulite: XCS-062-5SG) であり, 図 3 にその概略を示 す.この半導体トランスデューサを図 2 のマイクロ静 圧管のフレア部に埋め込むことにより, 非常に小型な

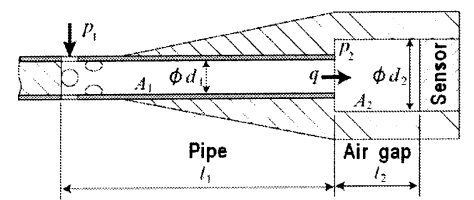

Fig. 1 The schematic of probe

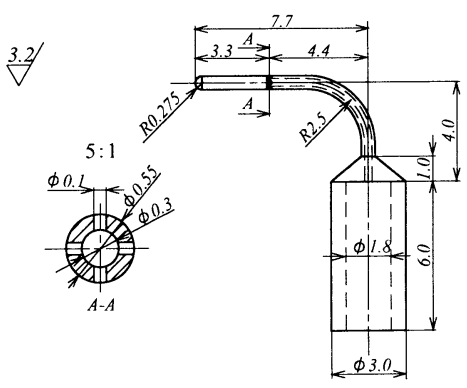

Fig. 2 The micro static tube

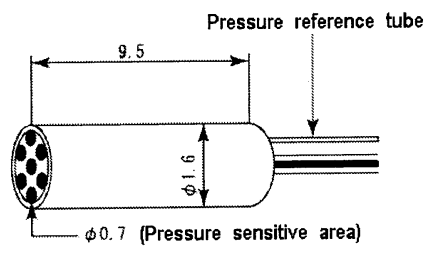

Fig. 3 The semiconductor transducer

静圧管プローブが完成した. 以後, この静圧管プロー ブをマイクロ静圧管プローブと称する.

3.3 マイクロ静圧管による一様流中の圧力測定 マイクロ静圧管が標準ピト一管と同様に一様流中で 平均静圧を測定できるかどうかを確かめるため, 正方 形噴流風洞 (図 4 に示される風洞, 出口寸法は $80 \mathrm{~mm}$ × $80 \mathrm{~mm}$ ) のポテンシャルコア内の一様流中でマイク ロ静圧管と微圧インジィータ (豊田工機: AA6610, 最 大測定可能圧力: $100 \mathrm{~Pa}$ ) を用いて圧力の測定を行なっ た。噴流出口速度 $U_{0}$ は $0 \sim 30 \mathrm{~m} / \mathrm{s}$ である.

図 5 に一様流中でマイクロ静圧管と微圧インジケー タを用いて圧力測定を行なった結果を示す. 横軸は正 方形噴流風洞の出口速度 $U_{0}$ を, 縦軸はマイクロ静圧 管を通し, 微圧インジケータにより測定された出力電 圧 $E_{p}$ を示す. $E_{p}$ は流速に比例するので, 各流速にお ける静圧の基準值は, 標準ピト一管での静圧測定電圧 值と考えることができる. この結果から, マイクロ静 圧管は出口速度 $U_{0}$ が $0<U_{0}<15 \mathrm{~m} / \mathrm{s}$ の範囲において, 誤差 $5 \%$ 以内で標準ピト一管と同様に平均静圧が測定 できることがわかる. 


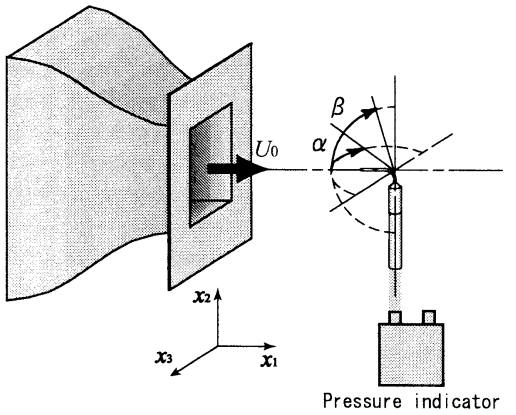

Fig. 4 Experimental device and coordinate system of direction test

\section{4 方向特性検定}

3.4.1 方向特性検定法 マイクロ静圧管プロー ブの方向特性の検定には, 第 3.3 節で説明した風洞と 同じ正方形噴流風洞 (図 4参照) を使用した. 出口速度 は $U_{0}=10,15,20 \mathrm{~m} / \mathrm{s}$ で行なった. マイクロ静圧管の 方向特性検定では，流れに対して $x_{2}$ 軸周りに $\alpha$ 傾斜, また $x_{3}$ 軸周りに $\beta$ 傾斜させたときの圧力を微圧イン ジケータにより測定を行った。測定值は次式により無 次元化された.

$$
C_{p}=\left(P_{\alpha}-P_{0}\right) /\left(\rho U_{0}^{2} / 2\right)
$$

ここで, $P_{0}$ は傾斜角 $\alpha=0^{\circ}$ における平均静圧, $U_{0}$ は 出口速度, $\rho$ は密度である.

3.4.2 方向特性の検定結果図 6 に噴流出口速 度 $U_{0}=10,15,20 \mathrm{~m} / \mathrm{s}$ でのマイクロ静圧管の傾斜角 $\alpha$ に対する方向特性検定結果を示す. いずれの噴流出口 速度においても， $|\alpha|<15^{\circ}$ に対して $P_{0}$ とのずれは動 圧に対して約 $5 \%$ であった. 図7 亿傾斜角 $\beta$ に対する 方向特性検定結果を示す. $-15^{\circ}<\beta<40^{\circ}$ に対して $P_{0}$ とのずれは動圧に対して約 $5 \%$ あっあた。 これらの 結果から, マイクロ静圧管は傾斜角が約 $15^{\circ}$ 以内にお いて $P_{0}$ とのずれは動圧に対して約 $5 \%$ であることが わかる.

\section{5 周波数応答特性検定}

3.5.1 周波数応答特性検定法 図 8 にマイクロ 静圧管プローブの周波数検定用の実験装置の測定系を 示す.この検定は，外部からの騒音を避けるため防音 室内にて行う。まず，スピーカーから $50 \mathrm{~mm}$ 離れた位 置に参照用圧力センサ (Kulite: XCS-062-5SG) または マイクロ静圧管プローブの静圧孔がくるように設置す る. そして，オシレーターで発生させた $100 \sim 20,000$ $\mathrm{Hz}$ の正弦波をオーディオアンプ (BOSE 社製)により 増幅させ，スピーカー (BOSE 社製) から音波として放 出させる．参照用圧カセンサまたはマイクロ静圧管プ

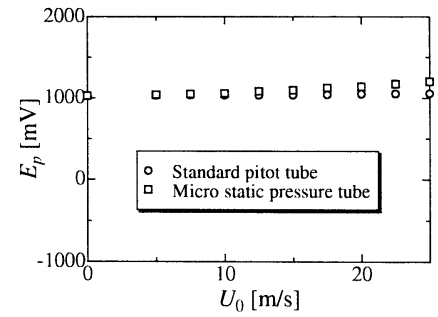

Fig. 5 The result of pressure measurement by the micro static tube

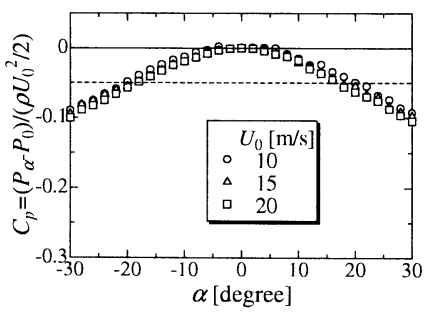

Fig. 6 Direction characteristic vs. $\alpha$

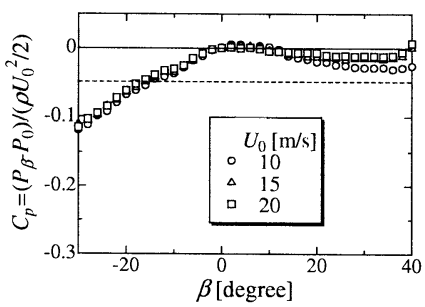

Fig. 7 Direction characteristic vs. $\beta$

ローブにより計測された音波は電圧信号に変換され, センサアンプによって 5,000 倍に増幅されて，このア ンプに内蔵されているローパスフィルター $(10 \mathrm{kHz})$ を 通した後に電圧計とオシロスコープに取り込まれる。 また，オシレーターで発生した正弦波の波形は，オー ディオアンプを通してスピーカーへ入力される電圧信 号からオシロスコープにより確認し，その信号の位相 と参照用圧力センサ及びマイクロ静圧管プローブの位 相との位相差 $\varphi_{1}, \varphi_{2}$ を測定する。 また，参照用圧力 センサの振幅測定值を $p_{1}$, マイクロ静圧管プローブ の振幅測定值を $p_{2}$ とする.このとき，振幅比 $M$ 及び 位相差 $\varphi$ は次式のように定義される.

$$
M \equiv p_{2} / p_{1}, \quad \varphi \equiv \varphi_{2}-\varphi_{1}
$$

3.6 周波数応答検定の実駼結果 振幅比 $M$ と位 相差 $\varphi$ の実験結果をそれぞれ図 9, 図 10 に示す。こ の結果から, 約 $2,500 \mathrm{~Hz}$ にヘルムホルツ共鳴点が確 認できる，なお，図中の実線は本実験で確認された共 


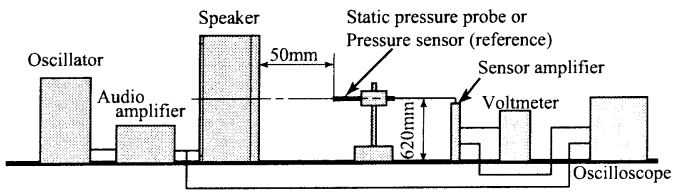

Fig. 8 Experimental set up for the examination of the characteristics of frequency response

鳴点を用いて計算された測定圧力が静圧孔上での圧力 に対して二次遅れ系の微分方程式に従うと仮定したと きの振幅比と位相差の近似曲線(7)である. 以下に，こ の近似曲線に対する理論の概略 ${ }^{(8)}$ を説明する.

静圧管プローブの共鳴周波数の近似曲線は, 次式よ り求まる伝達関数の重社合わせとして扱うことで求め ることができる．ここで， $L, R, C$ はそれぞれ流体イ ナータンス, 流体抵抗, 流体キャパシタンスと呼ばれ るものであり, 流体イナータンスは流体の急激な移動 により，流体抵抗は流体の粘性力により，流体キャパ シタンスは流体の圧縮性の影響によりそれぞれ生じる.

$$
L C \frac{d^{2} p_{2}}{d t^{2}}+R C \frac{d p_{2}}{d t}+p_{2}=p_{1}
$$

上式をラプラス変換すると, 伝達関数 $G_{n}(s)$ が求まる.

$$
\begin{aligned}
G_{n}(s) & =\frac{P_{2}(s)}{P_{1}(s)}=\frac{1}{L C s^{2}+R C s+1} \\
& =\frac{1}{\left(s / \omega_{n}\right)^{2}+2 \zeta_{n}\left(s / \omega_{n}\right)+1}
\end{aligned}
$$

ここで, $\omega_{n}=1 / \sqrt{L C}$ は固有角振動数, $\zeta_{n}=R \sqrt{C / L} / 2$ は減衰比である.この周波数伝達関数 $G_{n}(j \omega)$ は次式 で表される。

$$
G_{n}(j \omega)=\frac{1}{\left(1-\left(\omega / \omega_{n}\right)^{2}\right)+j 2 \zeta\left(\omega / \omega_{n}\right)}
$$

この周波数伝達関数 $G_{n}(j \omega)$ の振幅 $\left|G_{n}(j \omega)\right|$ と位相差 $\varphi_{n}$ は次式で表される.

$$
\begin{aligned}
\left|G_{n}(j \omega)\right| & =\frac{1}{\sqrt{\left\{1-\left(f / f_{n}\right)^{2}\right\}^{2}+4 \zeta_{n}^{2}\left(f / f_{n}\right)^{2}}} \\
\varphi_{n} & =-\tan ^{-1} \frac{2 \zeta_{n}\left(f / f_{n}\right)}{1-\left(f / f_{n}\right)^{2}}
\end{aligned}
$$

図 11 に示すような伝達関数 $G_{n}(s)$ の重ね合わせの 場合, 振幅 $\left|G_{n}(j \omega)\right|$ と位相差 $\varphi_{n}$ は次式で表される.

$$
\begin{aligned}
|G(j \omega)| & =\left|G_{1}(j \omega)\right|\left|G_{2}(j \omega)\right| \cdots\left|G_{N}(j \omega)\right| \\
& =\prod_{n=1}^{N}\left|G_{n}(j \omega)\right|
\end{aligned}
$$

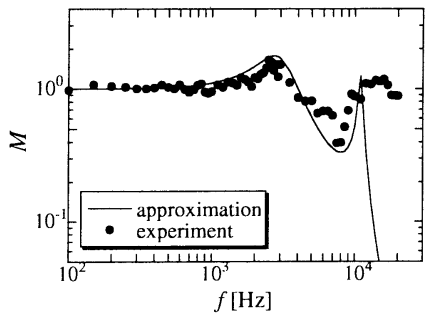

Fig. 9 Ratio of magnitude $M$ vs. frequency $f$

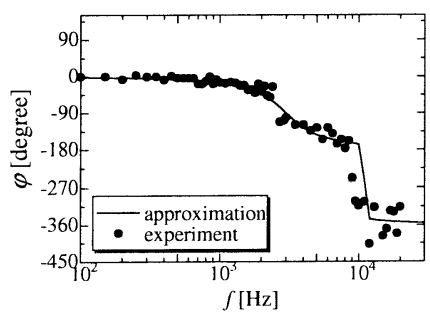

Fig. 10 Phase difference $\varphi$ vs. frequency $f$

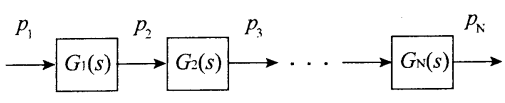

Fig. 11 Superposition of transfer function

$$
\varphi=\varphi_{1}+\varphi_{2}+\cdots+\varphi_{N}=\sum_{n=1}^{N} \varphi_{n}
$$

従って, ヘルムホルツ共鳴周波数とオルガンパイプ共 鳴周波数をそれぞれ $f_{1}, f_{2}$, それに対応した減衰比を それぞれ $\zeta_{1}, \zeta_{2}$ とすると, 静圧管プローブの周波数 応答特性における振幅比 $|G|$ と位相差 $\varphi$ は次式で求め ることができる.

$$
\begin{gathered}
|G|=\frac{1}{\sqrt{\left\{1-\left(f / f_{1}\right)^{2}\right\}^{2}+4 \zeta_{1}^{2}\left(f / f_{1}\right)^{2}}} \\
\cdot \frac{1}{\sqrt{\left\{1-\left(f / f_{2}\right)^{2}\right\}^{2}+4 \zeta_{2}^{2}\left(f / f_{2}\right)^{2}}} \\
\varphi=-\tan ^{-1} \frac{2 \zeta_{1}\left(f / f_{1}\right)}{1-\left(f / f_{1}\right)^{2}}-\tan ^{-1} \frac{2 \zeta_{2}\left(f / f_{2}\right)}{1-\left(f / f_{2}\right)^{2}}
\end{gathered}
$$

3.7 二次元噴流の変動静圧測定 今回開発され たマイクロ静圧管プローブの有効性を検証するために, ここでは, 過去に特性がよく調べられている二次元噴 流 ${ }^{(9)}(10)$ における变動静圧の測定を行った. 


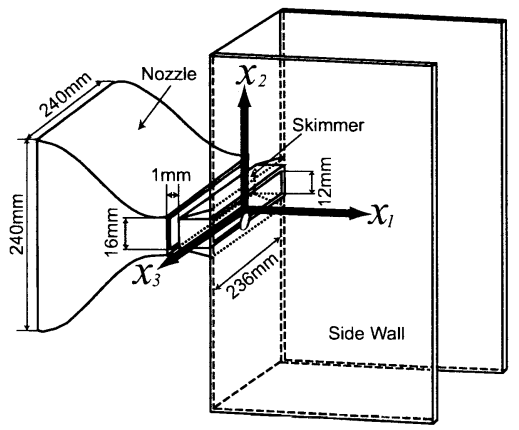

Fig. 12 Coordinate system of two-dimensional jet flow

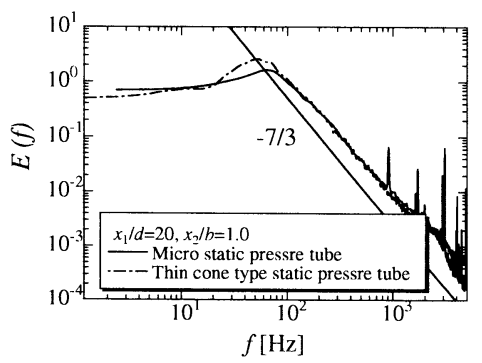

Fig. 13 Power spectra of fluctuating pressure on the twodimensional jet flow

3.7.1 実験装置と実験条件本研究で使用した 二次元噴流発生装置は, 著者らによる過去の報告(9) (10) で示したものと同じものである. 従って,ここでは装 置の簡単な説明のみ与える (詳細は文献 (9),(10) を参照 されたい), 図 12 に噴流出口付近の略図と座標系を示 す.ノズル出口から $1 \mathrm{~mm}$ 離れた場所にスキマーを設 置することにより, ノズル出口の流れの均一な部分の み取り出すことができる. 噴流出口 (スキマー出口) は 高さ $d=12 \mathrm{~mm}$ で, アスペクト比は 19.7 である. 座標 系は噴流軸方向を $x_{1}$, 垂直方向を $x_{2}$, スパン方向を $x_{3}$ とし, 噴出レイノルズ数 $\operatorname{Re}$ は $\operatorname{Re}=U_{0} d / v=22,000\left(U_{0}\right.$ : 噴流出口速度) に調節した. 測定は $x_{1} / d=20$ の断面 において乱れの強い $x_{2} / b \simeq 1.0(b$ : 噴流の平均速度分 布の半值幅) の位置とした.

3.7.2 変動静圧測定結果測定された変動静圧の パワースペクトルを図 13 に示す. 縦軸は無次元化し ておらずェネルギーの生の值を示している.なお, 図 13 中には著者らが先の実験 ${ }^{(7)}$ で使用した円錐先端型静 圧管プローブによる測定結果もあわせて示してある. 円錐先端型静圧管プローブは, 周波数応答の検定より, 約 $3 \mathrm{kHz}$ まで振幅比 $M=1.0$ で一定であり, 位相差 $\varphi$ もほとんど零であることが確かめられている ${ }^{(7)}$. 図
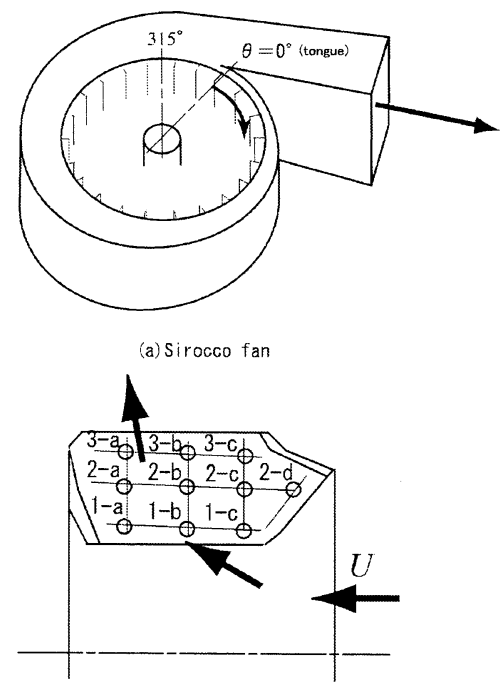

(b) Measurement positions

Fig. 14 Sirocco fan and measurement positions. The measurement positions are located between the adjacent blades

13 の結果から, 両者のスペクトルはほぼ一致してお り, -7/3 乗則の領域が確認されることから, 本研究で 開発したマイクロ静圧管プローブは静圧変動を十分精 度よく測定可能であることが確認された。

\section{4. 自動車用空調シロッコファン翼間の変動静圧の}

\section{測定}

ここでは, 前章で説明された新型マイクロ静圧管プ ローブを使用して, 具体的に, 自動車用シロッコファ ン翼閒の変動静圧の測定を行ったので, その結果を報 告する. なお, 予備実験により, 本研究で用いたシロッ コファンの主な騒音源が羽根車からの放射音であるこ とを確認している.

$4 \cdot 1$ 実験条件 図 14 に自動車用空調シロッコファ ンとファン翼間の変動静圧測定位置を示す. シロッコ ファン翼間の変動静圧の測定には, 図 2 , 困 3 に示すマ イクロ静圧管と半導体トランスデューサ (Kulite: XCS062-5SG) を組み合わせたマイクロ静圧管プローブを 使用した. 図 14(b) に示す翼面の 1-a〜3-c の位置で, ファン翼間の中心にマイクロ静圧管プローブを設置し た.ここで, 1-2 および 2-3 間の間隔は $9 \mathrm{~mm}, \mathrm{a}-\mathrm{b}, \mathrm{b}-\mathrm{c}$ および c-d 間の間隔は $15 \mathrm{~mm}$ である. なお, マイクロ 静圧管プローブの設置角度は, CFD により求められ た, 測定位置での平均流れの角度に調整した。

マイクロ静圧管プローブの出力電圧を, スリップリ ングに通し, その後センサアンプ (TEAC: SA-56) に 


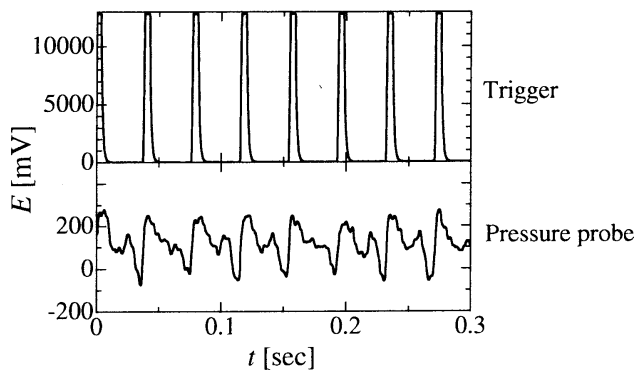

Fig. 15 Time history of static pressure signal (measurement point 1-b; cooling mode)

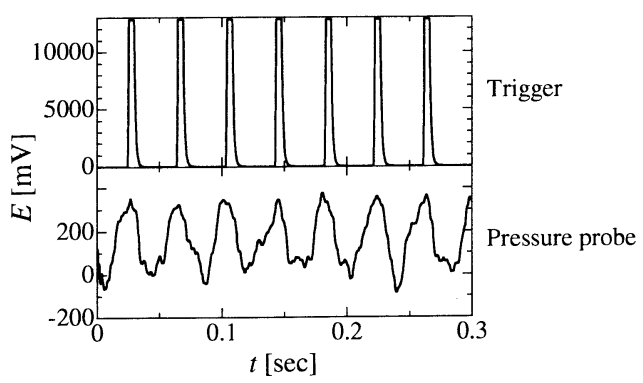

Fig. 16 Time history of static pressure signal (measurement point 1-b; heating mode)

より 5,000 倍に増幅し，PC (DELL: Dimension 1100) に搭載された $\mathrm{A} / \mathrm{D}$ ボード (MICRO SCIENCE: ADM688PCI) により 14 bit デジタル值に変換された後サン プリングされ，固定ディスクに瞬時電圧として記録さ れる.また，トリガー信号をかける位置は，図 14(a) の舌部とし, 得られたトリガー信号についても同様に 瞬時電圧として記録される.

ファンの回転数は $1,500 \mathrm{rpm}$, サンプリング周波数 は $20 \mathrm{kHz}$ でサンプリング点数は $2,097,152$ 点 (サンプ リング時間：約 105 秒) である.

また, 二種類の流路抵抗を用いて, 空調の冷房モー ド (cooling mode) と暖房モード (heating mode)の二種 類の条件で測定を行った。 なお, 流路抵抗は実際の運 転条件を考虑して, 冷房モードの抵抗が暖房モードの 抵抗より小さくなっており, 流量係数 $\phi(=(Q / A) / U$ : $Q$ : 流量; $A=\pi D^{2} / 4 ; D$ : 羽根車外径; $U$ : 羽根車外周 速度) は冷房モードにおいて 0.38, 暖房モードにおい て 0.18 である.また, 実際の実験では回転数は 1,500 rpm に固定されているので, 流量は二種類のモードで 異なることに注意されたい.

\section{2 シロッコファン翼間変動静圧の測定結果}

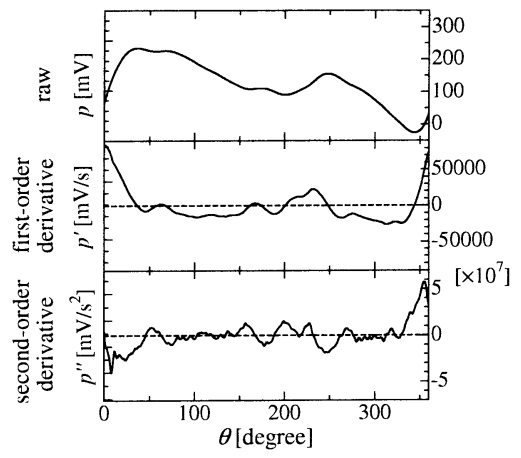

Fig. 17 Phase averaged signals (cooling mode)

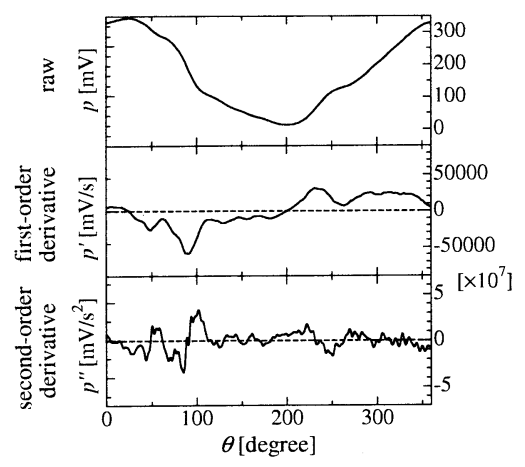

Fig. 18 Phase averaged signals (heating mode)

4.2.1 瞬時波形 ここでは, 二種類の流路抵抗を 用いて, 測定点 1-b で測定された変動静圧の瞬時波形 を示す. 図 15 が冷房モード (cooling mode) の結果を, 図 16 が暖房モード (heating mode) の結果を示してい る.なお, 出力変動電圧と変動静圧の換算率は 0.189 $\mathrm{Pa} / \mathrm{mV}$ である.これらの結果より, 舌部付近で静圧管 プローブから得られた電圧值が急増していることがわ かる.また cooling mode と heating mode で瞬時波形 が異なっていることがわかる.

\subsection{2 ファン翼間変動静圧の二階の時間微分} Ribner の式に基づき，ファン翼間変動静圧の二階の 時間微分值を求めるための処理手順を示す．まず， マ イクロ静圧管プローブから得られた瞬時電圧にデジタ ルローパスフィルターをかけ，2,000 Hz 以上の周波数 成分の信号をカットする. これは, 第 3 章のマイクロ 静圧管の周波数応答特性検定において, 約 $2,500 \mathrm{~Hz}$ でヘルムホルツ共鳴と考えられる共鳴点を確認したか らである. 次に, マイクロ静圧管プローブから得られ た瞬時電圧の時間に関する一階微分と二階微分を求め る. 微分の計算には, 四次精度の五点中心差分式を用 


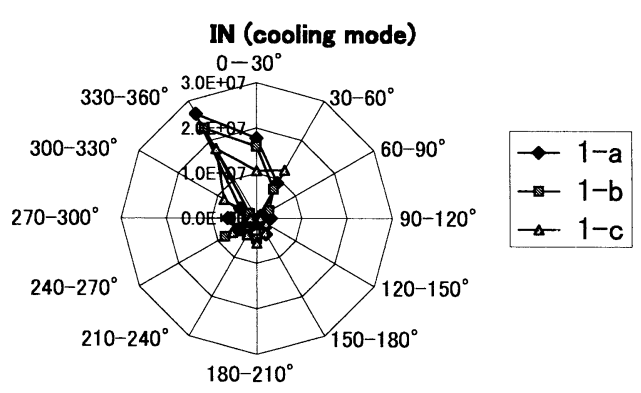

Fig. 19 Distributions of the interval r.m.s value of static pressure fluctuation (at the inlet of blade, cooling mode). The unit is $\left[\mathrm{mV} / \mathrm{s}^{2}\right]$

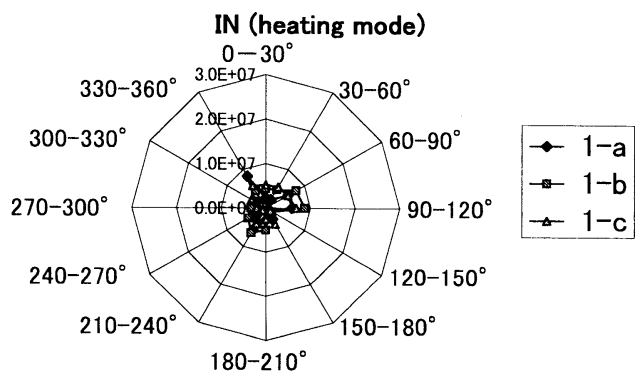

Fig. 20 Distributions of the interval r.m.s value of static pressure fluctuation (at the inlet of blade, heating mode). The unit is $\left[\mathrm{mV} / \mathrm{s}^{2}\right]$

いた. 最後に, 瞬時電圧と瞬時電圧の一階微分および 二階微分の位相平均を求める. なお, これら一連の計 算処理の精度については，正弦波を使用して，100〜 $5,000 \mathrm{~Hz}$ に渡って微分波形が理論波形と一致すること を確かめることによって検証を行っている.

測定点 1-b で測定された変動静圧の 1 回転分の位相 平均および, 変動静圧の一階微分と二階微分の位相平 均を冷房モード (cooling mode) について図 17 に, 暖 房モード (heating mode) について図 18 にそれぞれ示 す.なお，位相平均は測定点によって異なるが，2,500 〜2,700 回転分の信号の平均をとって得られたもので ある. これらの結果より, 瞬時電圧の傾きに整合した 微分值が計算されていることがわかる．変動静圧の時 間に関する二階微分は, Ribnerの式の音源項を示して おり，これにより音源項を定量化できたといえる.

\subsection{3 羽根車の周方向 $30^{\circ}$ 間隔毎の変動静圧の二} 階微分に対する二乗平均平方根の分布 Ribnerの 式の音源項を定量化することができたことで, さらに 音源の強い位置の特定を目指す.まず, 先に求めた変 動静圧の二階微分の位相平均を羽根車の周方向 (図 14 参照)に $30^{\circ}$ 間隔で 12 等分する. 次に, 各区間で二

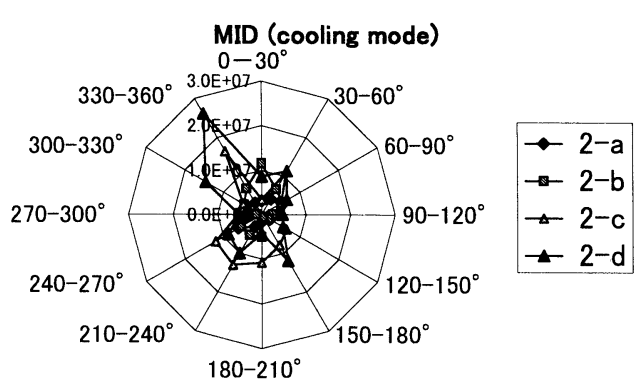

Fig. 21 Distributions of the interval r.m.s value of static pressure fluctuation (at the middle of blade, cooling mode). The unit is $\left[\mathrm{mV} / \mathrm{s}^{2}\right]$

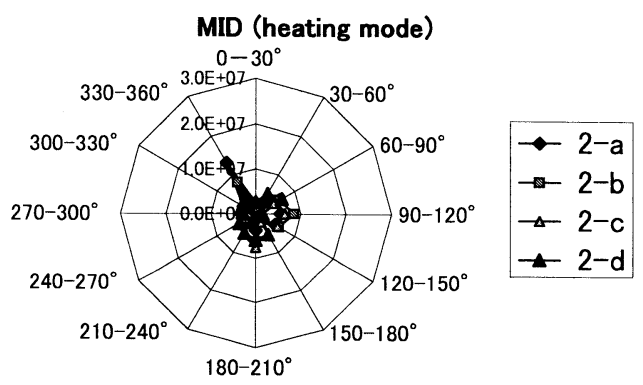

Fig. 22 Distributions of the interval r.m.s value of static pressure fluctuation (at the middle of blade, heating mode). The unit is $\left[\mathrm{mV} / \mathrm{s}^{2}\right]$

乗平均の平方根（これを区間二乗平均平方根と呼ぶこ とにする）をとり，その值をその区間の音源の強さの パラメータとする. そして全ての区間で区間二乗平均 平方根を求める.

$30^{\circ}$ 間隔毎の変動静圧の二階微分に対する二乗平均 平方根の分布を以下に示す. 図 19, 図 20 はそれぞれ 翼入口 (IN) の cooling mode, heating mode の結果を, 図 21, 図 22 はそれぞれ翼中間 (MID) の cooling mode, heating mode の結果を, 図 23, 図 24 はそれぞれ翼出 口 (OUT) の cooling mode, heating mode の結果を示し ている. 図中の值の単位は $\left[\mathrm{mV} / \mathrm{s}^{2}\right]$ である. 図 19, 図 20 より, 舌部直前で cooling mode の区間二乗平均平 方根が heating mode の区間二乗平均平方根より大きい ことがわかる. また, 図 21 , 図 22 からは, 全体的に cooling mode の方が heating mode より区間二乗平均平 方根が大きいことがわかる. 図 23, 図 24 でも同様に, cooling mode の区間二乗平均平方根が heating mode $の$ それより大きく，乱部で最も大きくなっている.

一般的に暖房モードよりも冷房モードのほうが比騒 音が大きいことが知られており，今回の実験結果と一 致する. また, 本研究によって舌部での騒音が大きい 


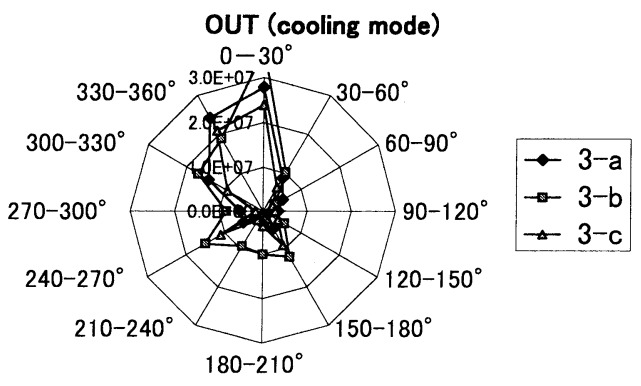

Fig. 23 Distributions of the interval r.m.s value of static pressure fluctuation (at the outlet of blade, cooling mode). The unit is $\left[\mathrm{mV} / \mathrm{s}^{2}\right]$

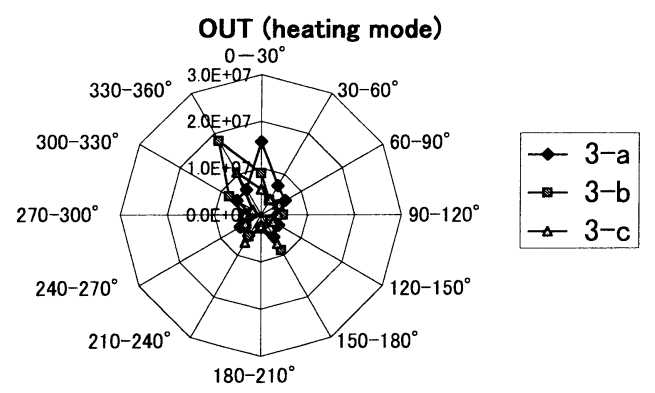

Fig. 24 Distributions of the interval r.m.s value of static pressure fluctuation (at the outlet of blade, heating mode). The unit is $\left[\mathrm{mV} / \mathrm{s}^{2}\right]$

ことが示唆され, 自動車用空調シロッコファンにおけ る音源の強い位置を特定することができた.

\section{5. お わりに}

本研究で得られた結果を以下にまとめる.

1. 今回新たに開発したマイクロ静圧管プローブの 角度特性を調べた結果，主流に対する傾斜角が約 $\pm 15^{\circ}$ の範囲で動圧に対するずれが約 $5 \%$ 以内で あった。

2. 開発したマイクロ静圧管プローブの周波数応答特 性を調べた結果，約 $2,500 \mathrm{~Hz}$ でヘルムホルツ共 鳴による共鳴点が確認された.

3. マイクロ静圧管プローブの実際の乱流場での有 効性を確かめるため, 二次元噴流場において静圧 場の測定を行った. その結果, 変動静圧 r.m.s 值 がピークを持つ位置では変動静圧のスペクトル に-7/3 乗則の領域が確認された.

4. 開発したマイクロ静圧管プローブを用いて, シ ロッコファン翼間の変動静圧を測定することがで きた.
5. 静圧変動の時間に関する二階微分值を求めること により, Ribnerの式の音源項を定量化することが できた。

6. 定量化した音源項から羽根車の周方向に $30^{\circ}$ 間隔 毎の二乗平均平方根を求めることで，翼が舌部を 通過する際に音源項が大きくなること, 冷房モ一 ドの音源が暖房モードの音源よりも大きな值を示 すことがわかった。

\section{謝辞}

本研究の一部は, 株式会社デンソーから共同研究資 金の援助を受けて行われた，記して謝意を表する.

\section{文献}

(1) Morinushi, K., Noise Source of a Multiblade Fan (in Japanese), Transactions of the Japan Society of Mechanical Engineers, Series B, Vol.57, No.543 (1991), pp. 3837-3844.

(2) Ribner, H. S., Aerodynamic Sound from Fluid Dilatation, Institute of Aerophysics Report, No. 86, University of Toronto, (1962).

(3) Ribner, H. S., Perspectives on Jet Noise, AIAA Journal, Vol.19, No.12 (1981), pp.1513-1526.

(4) Shirahama, Y. and Toyoda, K., Development of the Probe to Measure Static-Pressure Fluctuations (Application to the Measurements of Jets) (in Japanese), Transactions of the Japan Society of Mechanical Engineers, Series B, Vol.59, No.567 (1993), pp.3381-3387.

(5) JSME Data Book: Flow Measurements (ed: The Japan Society of Mechanical Engineers, in Japanese) (1985), pp.34-66,

(6) Ishida, T., Toyoda, K., Tao, H. and Shirahama, Y., Study of Yaw-Angle Characteristics of Static Pressure Probe, Proceedings of Fluids Engineering Division Conference of the Japan Society of Mechanical Engineers, No.95-19 (1995), pp.169-170.

(7) Sakai, Y., Moriguchi, Y., Tanaka, N., Yamamoto, M., Kubo, T. and Nagata, K., On Characteristics of Velocity and Pressure Field in Two-Dimensional Turbulent Jet, Journal of Fluid Science and Technology, Vol.2, No.3 (2007), pp.611-622.

(8) Ito, M., Automatic Control (Shokodo Inc.), Vol.1 (1983).

(9) Sakai, Y., Tanaka, N. and Kushida, T., On the Development of Coherent Structure in a Plane Jet (Part1, Characteristics of Two-point Velocity Correlation and Analysis of Eigenmodes by the KL Expansion), JSME International Journal, Series B, Vol.49, No.1 (2006), pp.115-124.

(10) Sakai, Y., Tanaka, N. and Kushida, T., On the Development of Coherent Structure in a Plane Jet (Part2, Investigation of Spatio-Temporal Velocity Structure by the KL Expansion), JSME International Journal, Series B, Vol.49, No.3 (2006), pp.714-721. 